\title{
Silicic acid biogeochemistry in the Gulf of California: Insights from sedimentary $\mathrm{Si}$ isotopes
}

\author{
Laetitia Pichevin, ${ }^{1}$ Raja S. Ganeshram, ${ }^{1}$ Ben C. Reynolds, ${ }^{2}$ Fredrick Prahl, ${ }^{3}$ \\ Thomas F. Pedersen, ${ }^{4}$ Robert Thunell, ${ }^{5}$ and Erin L. McClymont ${ }^{6}$ \\ Received 29 September 2011; revised 20 December 2011; accepted 2 February 2012; published 5 April 2012.
}

[1] Iron is considered to play a large role in the cycling of $\mathrm{Si}$ in Fe-limited regions of the ocean, but little is known about its role in Si biogeochemistry outside these areas. Here, we present published sediment trap data, new nutrient profiles and high resolution sedimentary records (Si isotopes, Biogenic silica\%, N\% and $\mathrm{C} \%$ ) from the Gulf of California, a non-Fe-limited region, to investigate the history of Si cycling in this highly productive basin. Modern nutrient profiles show that silicic acid in subsurface waters is in excess relative to nitrate and is therefore incompletely utilized during moderate winter upwelling events. Modern data, however, suggest that during intense upwelling episodes, silicic acid is preferentially utilized relative to nitrate by the biota, which we suggest reflects transient iron limitation. Our new $\delta^{30} \mathrm{Si}$ record from the Guaymas Basin shows dramatic variations at millennial timescales. Low $\delta^{30} \mathrm{Si}$ values synchronous with Heinrich events are interpreted as resulting from the decline in $\mathrm{Si}(\mathrm{OH})_{4}$ utilization at times of decreased upwelling strength, while nearly complete $\mathrm{Si}(\mathrm{OH})_{4}$ utilization was observed at times of invigorated upwelling and increased opal burial during the Holocene, the Bølling-Allerød and the last glacial period. We attribute the complete utilization of $\operatorname{Si}(\mathrm{OH})_{4}$ to the occurrence of transient Fe limitation at these times. Our study highlights the importance of Fe limitation on $\mathrm{Si}$ and $\mathrm{C}$ cycling in coastal upwelling regions and suggests that upwelling dynamics, in combination with Fe availability, have the potential to modulate marine Si distribution and opal burial even at short timescales.

Citation: Pichevin, L., R. S. Ganeshram, B. C. Reynolds, F. Prahl, T. F. Pedersen, R. Thunell, and E. L. McClymont (2012), Silicic acid biogeochemistry in the Gulf of California: Insights from sedimentary Si isotopes, Paleoceanography, 27, PA2201, doi:10.1029/2011PA002237.

\section{Introduction}

[2] Silicic acid is an essential nutrient for siliceous phytoplankton growth [Ragueneau et al., 2000, and references therein]. Diatoms, the main siliceous phytoplankton group, account for up to $40 \%$ of marine primary production [Nelson et al., 1995] and dominate phytoplankton communities in the Southern Ocean (SO), the North Pacific and the equatorial and tropical Pacific upwelling regions [e.g., Lisitzin, 1971]. In these vast, highly productive areas, silicic acid availability sets the upper limit to the total primary production and carbon export, implying a coupling between marine

\footnotetext{
${ }^{1}$ School of Geosciences, Grant Institute, University of Edinburgh, Edinburgh, UK.

${ }^{2}$ IGMR, ETH Zürich, Zürich, Switzerland.

${ }^{3}$ College of Oceanic and Atmospheric Sciences, Oregon State University, Corvallis, Oregon, USA.

${ }^{4}$ School of Earth and Ocean Sciences, University of Victoria, Victoria, British Columbia, Canada.

${ }^{5}$ Department of Earth and Ocean Sciences, University of South Carolina, Columbia, South Carolina, USA.

${ }^{6}$ Department of Geography, University of Durham, Durham, UK.

Copyright 2012 by the American Geophysical Union. 0883-8305/12/2011PA002237
}

Si and C cycles [Chai et al., 2002; Dugdale and Wilkerson, 1998; Dugdale et al., 1995]. In addition, by favoring siliceous over calcareous phytoplankton, modifications in the cycling of silicic acid in the ocean have the potential to alter the marine $\mathrm{C}$ rain rate ratio (the ratio of organic to inorganic carbon) and the amount of carbon that can be stored in the ocean interior. For instance, increased inventory and/or redistribution of silicic acid in key areas of the ocean has been proposed to have contributed to the lowering of atmospheric $\mathrm{PCO}_{2}$ during the last glacial periods [Archer and Maier-reimer, 1994; Brzezinski et al., 2002; Harrison, 2000; Matsumoto et al., 2002; Pichevin et al., 2009]. Therefore, understanding biogeochemical Si cycling and the distribution and inventory of this nutrient in the ocean is critical for determining its role in the global $\mathrm{C}$ cycle and long-term climate change.

[3] The distribution and cycling of silicic acid in the ocean differs from those of other essential nutrients like nitrate and phosphate [Broecker and Peng, 1984]. Almost everywhere, the surface and the intermediate ocean is currently depleted in $\mathrm{Si}(\mathrm{OH})_{4}$ compared to $\mathrm{NO}_{3}{ }^{-}$relative to proportions consumed by biota whereas silicic acid accumulates in the deep ocean, especially the Pacific basin. This has been attributed to two factors: first, the faster decay of organic matter 
compared to opal dissolution as particles settle through the water column [Broecker and Peng, 1984]; second, to the low preformed $\left[\mathrm{Si}(\mathrm{OH})_{4}\right]$ relative to $\left[\mathrm{NO}_{3}{ }^{-}\right]$in intermediate waters sourced from the $\mathrm{SO}$ and North Pacific [Sarmiento et al., 2004, 2007]. The low performed $\mathrm{Si}(\mathrm{OH})_{4}: \mathrm{NO}_{3}{ }^{-}$ratio in intermediate waters formed in the SO results from the exhaustion of silicate relative to nitrate due to iron limitation. It has been shown in this region that the Fe stressed diatoms are heavily silicified and the uptake of $\mathrm{Si}(\mathrm{OH}) 4$ relative to $\mathrm{NO}_{3}$ is high [Brzezinski et al., 2002; Hutchins and Bruland, 1998; Takeda, 1998]. Hence, the endemic $\mathrm{Fe}$ limitation prevailing in the SO today, could potentially explain: (1) the exceptionally high biogenic silica (bioSi) accumulation in the SO seafloor [Pondaven et al., 2000]; (2) the low preformed $\mathrm{Si}(\mathrm{OH})_{4}: \mathrm{NO}_{3}{ }^{-}$ratio in the mode/ intermediate waters originating from this area [Sarmiento et al., 2007]; and (3) the silicic acid limitation in parts of the low latitude surface ocean fed by SO sourced intermediate waters [Moore et al., 2004]. These suggestions highlight the intimate coupling between the biogeochemical cycles of $\mathrm{Fe}, \mathrm{Si}$ and $\mathrm{C}$ in the global ocean.

[4] In contrast, very little is known about the effect of $\mathrm{Fe}$ availability on Si cycling and opal burial in coastal upwelling systems. In ocean margins, Fe limitation during diatom growth occurs only as a transient condition associated with upwelling and high productivity [Hutchins and Bruland, 1998]. The Gulf of California (GC), characterized by outstandingly high diatom productivity [Thunell et al., 1993] and bioSi accumulation, is not affected by year-round iron limitation like the other high bioSi accumulating regions (SO, North Pacific, Equatorial Pacific), which makes this area an ideal case study for the role of iron in the cycling of silicic acid. Here, we first review modern nutrient utilization and biogenic exports in relation to upwelling changes in the Guaymas Basin of the Gulf of California, using published sediment trap data and nutrient profiles. Second, we use new, high resolution Si-isotope data obtained from a welldated proximal sediment core to document past changes in silicic acid availability/utilization and interpret historical variability in bioSi and organic $\mathrm{C}$ export fluxes.

\section{Material and Methods}

[5] The collection site for the sediment core studied is identified on the map in Figure 1. Calypso Core MD-02 2515 was retrieved from the Guaymas Basin $\left(27^{\circ} 29.01 \mathrm{~N}\right.$; $112^{\circ} 04.46 \mathrm{~W} ; 881 \mathrm{~m}$ water depth) during the MONA (Marges Ouest Nord Américaines) cruise of the R/V Marion Dufresne (International Marine Global Changes-IMAGES VIII) in June 2002.

[6] The core is well dated with an age model based on $28 \mathrm{AMS}^{14} \mathrm{C}$ assays of organic matter (Table 1). Organic matter in this highly productive, rapidly accumulating site is of marine origin (as confirmed by stable $\mathrm{C}$ isotope measurements-not shown- and biomarker analyses of organic matter [McClymont et al., 2012]). This reflects the fact that foraminiferal carbonate is scarce with the exception of few intervals where dating on foraminifera was possible. Hence, radiocarbon dating on the more abundant organic carbon fraction offers the opportunity to date the record at high resolution and on crucial intervals while achieving greater precision. Two additional ${ }^{14} \mathrm{C}$ measurements made on planktonic foraminifers agree well with the organic matter ages (Table 1). Note that foraminiferal dates integrate a $3 \mathrm{~cm}$ sample slices as opposed to $1 \mathrm{~cm}$ in the case of organic matter based dates. Calibration to calendar ages B.P. was done by applying MARINE04 software (http://calib.qub.ac.uk/calib/) [Reimer et al., 2004] for radiocarbon dates younger than $21 \mathrm{kyr}$ and the equation of Bard et al. [2004] for older ages. We applied total reservoir ages of $600 \mathrm{yrs}$ in accordance with previous studies [Berger et al., 1966; Ganeshram et al., 1995] (see also http://calib. qub.ac.uk).

[7] Determination of the bioSi content (\%) was performed by sodium carbonate sequential leaching following Mortlock and Froelich [1989]. Analytical precision is 2\%. Organic Carbon (Corg, \%) and N (\%) contents were determined by using a Carlo-Erba elemental analyzer. All the above data have been produced at the School of Geosciences, the University of Edinburgh, with a temporal resolution equivalent on average to 40 years. Analytical precision of the instrument based on multiple analyses of a laboratory bulk sediment standard is $+0.2 \%$ ( 1 sigma).

[8] Purification of the diatom samples for silicon isotope measurement was performed following published cleaning methods [Morley et al., 2004]. The cleaning procedure includes sieving and elimination of large debris as well as screening of the sample under the microscope to verify the purity of the diatom fraction. For silicon isotope determinations, a small amount of bioSi $(0.5 \mathrm{mg})$ was dried down with concentrated perchloric acid at $\sim 180^{\circ} \mathrm{C}$ in Teflon $(\mathrm{C}$ vials, and then dissolved in $100 \mu \mathrm{L}$ of $1 \mathrm{M} \mathrm{NaOH}$, before being neutralized with $0.01 \mathrm{M} \mathrm{HCl}$ and diluted to $5 \mathrm{ml}$ after $24 \mathrm{~h}$. An aliquot equivalent to $10 \mu \mathrm{g}$ of bioSi was loaded onto a pre-cleaned $1.8 \mathrm{ml}$ DOWEX0W-X12 cation exchange resin bed (in $\mathrm{H}^{+}$form) and eluted with $5 \mathrm{ml}$ of purified water (Milli-Q element 18.2 M $\Omega . \mathrm{cm}^{-1}$ ). The Si isotope composition of the diluted solution $(0.6 \mathrm{ppm} \mathrm{Si})$ was determined using a Nu1700 high-resolution MC-ICPMS at ETH Zürich and a standard-sample-standard bracketing protocol [Reynolds et al., 2006b]. All results in this study were calculated using the $\delta^{30} \mathrm{Si}$ notation for deviations in parts per thousand (\%) from the measured ${ }^{30} \mathrm{Si} /{ }^{28} \mathrm{Si}$ ratio in the international Si standard NBS28. The long-term reproducibility was better than $0.14 \%$ o $\delta^{30} \mathrm{Si}(2 \sigma$ s.d.) [Reynolds et al., 2006b]. Samples were measured at least five times, which resulted in a $95 \%$ confidence level for each individual sample of better than plus/minus $0.08 \%$.

[9] We use modern $\mathrm{Si}(\mathrm{OH})_{4}$ and $\mathrm{NO}_{3}{ }^{-}$profiles collected in the Guaymas Basin in summer 2004 and winter 2005 as well as annual, seasonal and monthly flux data from the Guaymas Basin published by Thunell [1998]. Nitrate profiles are published by Malinverno et al. [2008] and White et al. [2007] and previously unpublished data for silicic acid profiles were provided by F. Prahl (2005).

\section{Silicic Acid Cycling in the Modern Guaymas Basin}

[10] The GC (Figure 1) has long been recognized as the type of oceanographic setting where intense coastal upwelling leads to formation of diatom-rich sediments [Calvert, 1966]. Vigorous northwesterly winds induce 


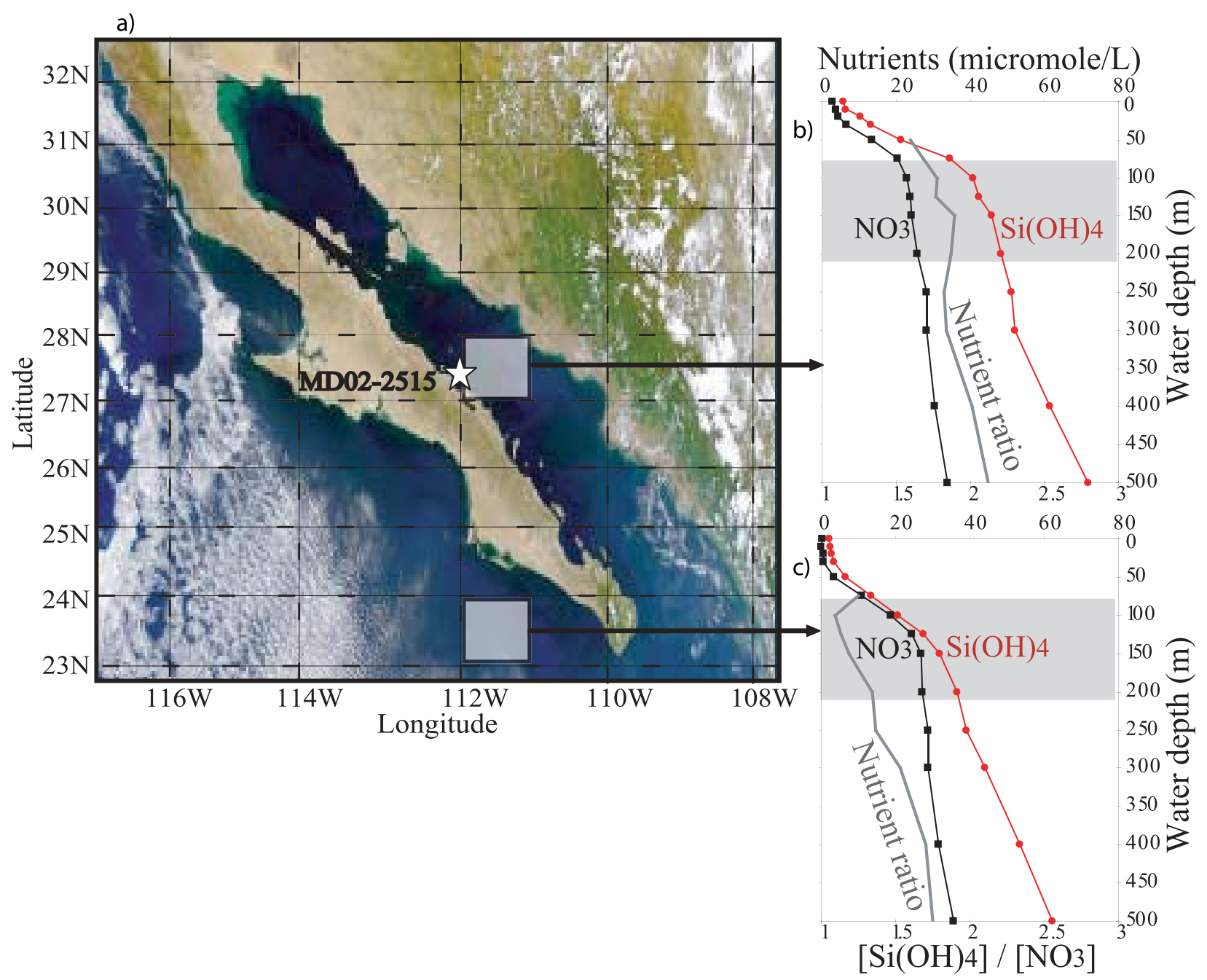

Figure 1. (a) Map of the Gulf of California. Location of Core MD 02-2515 is shown on the map with a white star. Insets present the hydrographic depth profiles for silicic acid and nitrate concentration (annual average) and the ratio of these two nutrient properties in the upper water column at (b) $111.5 \mathrm{~W}, 27.5 \mathrm{~N}$ and (c) $111.5 \mathrm{~W}, 23.5 \mathrm{~N}$ from the World Ocean Atlas (http://iridl.ldeo.columbia.edu/SOURCES/.NOAA/. NODC/.WOA01/). Silicic acid concentration in the intermediate and subsurface waters in the Guaymas Basin is unusually high, as shown by the annually averaged $\left[\mathrm{Si}(\mathrm{OH})_{4}\right]$ profiles from the $\mathrm{GC}$ compared to the open Pacific.

mixing and upwelling in late fall to early spring, bringing nitrate and silicic acid to the surface ocean from below [Roden, 1958]. In summer, the wind weakens and reverses, halting diatom blooms and resulting in lower primary production and biogenic fluxes in the basin [Sancetta, 1995; Thunell, 1998; Ziveri and Thunell, 2000]. The monsoonal regime of the GC is governed by the latitudinal shift of the Inter-Tropical Convergence Zone (ITCZ) and causes a reversal of both the atmospheric and surface ocean circulation, triggering an outflow of water from the Gulf in late fallearly spring and an inflow of equatorial waters throughout the summer [Bray, 1988; Roden, 1958].

[11] Upwelling in the GC is extremely sensitive to large scale climate oscillation in the Pacific ocean-atmosphere system and primary production in this area has been shown to respond strongly to ENSO (El Niño-Southern Oscillation) perturbations [Sancetta, 1995; Thunell, 1998].

\subsection{Seasonal and Interannual Variations in Biogenic Fluxes}

[12] Figure 2 shows the seasonal variability in opal, organic carbon, terrigenous and calcium carbonate export fluxes in the Guaymas Basin. The average fluxes are calculated from existing trap data collected between July 1990 and December 1996 [Thunell et al., 1993; Thunell, 1998]. These data confirm the seasonal cyclicity in bioSi export in the Gulf of California, with high values during the upwelling season between November and March and low values throughout the rest of the year. Trap data indicate that siliceous-producers represent between 40 and $95 \%$ of the biogenic fluxes in the GC; hence organic fluxes are expected to vary in tandem with bioSi fluxes. Surprisingly, this is not the case as seen in Figure 2. The organic carbon fluxes are relatively stable year-round despite drastic seasonal changes in upwelling intensity, productivity and bioSi export [Thunell 
Table 1. Radiocarbon ${ }^{14} \mathrm{C}$ Dates and Calibrated Ages for Core MD 02-2515

\begin{tabular}{|c|c|c|c|c|}
\hline Material & Depths $(\mathrm{cm})$ & $\mathrm{AMS}^{14} \mathrm{C}$ Ages & Error, 1 sigma (years) & Calendar Age (years B.P.) \\
\hline Organic carbon & 192 & 6571 & 45 & 6840 \\
\hline Organic carbon & 426 & 7990 & 37 & 8256 \\
\hline Organic carbon & 631 & 9438 & 40 & 10077 \\
\hline Organic carbon & 846 & 10517 & 42 & 11293 \\
\hline Organic carbon & 1119 & 12589 & 97 & 13854 \\
\hline Organic carbon & 1445 & 14767 & 62 & 16894 \\
\hline Organic carbon & 2006 & 16306 & 164 & 18932 \\
\hline Foraminifera & 2520 & 18397 & 60 & 21007 \\
\hline Organic carbon & 2520 & 18383 & 60 & 20988 \\
\hline Organic carbon & 2753 & 19471 & 67 & 22391 \\
\hline Organic carbon & 2974 & 20972 & 78 & 24365 \\
\hline Organic carbon & 3071 & 22219 & 88 & 25553 \\
\hline Organic carbon & 3099 & 21994 & 86 & 25303 \\
\hline Foraminifera & 3666 & 25254 & 121 & 28866 \\
\hline Organic carbon & 3666 & 25943 & 133 & 29602 \\
\hline Organic carbon & 3901 & 27425 & 290 & 31165 \\
\hline Organic carbon & 4319 & 28556 & 335 & 32339 \\
\hline Organic carbon & 4346 & 29400 & 372 & 33205 \\
\hline Organic carbon & 4674 & 31519 & 503 & 35669 \\
\hline Organic carbon & 4721 & 34018 & 662 & 37784 \\
\hline Organic carbon & 4793 & 35736 & 820 & 39419 \\
\hline Organic carbon & 4927 & 37484 & 1023 & 41045 \\
\hline Organic carbon & 4982 & 38371 & 1140 & 41855 \\
\hline Organic carbon & 5017 & 40140 & 1422 & 43442 \\
\hline Organic carbon & 5138 & 43584 & 2184 & 46418 \\
\hline Organic carbon & 5506 & 43940 & $>3000$ & 49000 (tie point) \\
\hline Organic carbon & 6045 & 43940 & $>3000$ & 52500 (tie point) \\
\hline Organic carbon & 6191 & 43905 & $>3000$ & 54000 (tie point) \\
\hline
\end{tabular}

et al., 1993; Thunell, 1998]. Thunell [1998] first noted the mismatch between organic and bioSi fluxes but the reasons for such a decoupling remain unexplained.

[13] The relationship between organic and inorganic fluxes do not suggest a strong ballast effect of lithogenic, calcareous or diatomaceous materials on POC exports especially at times of high biosilica production [Armstrong et al., 2001; Francois et al., 2002; Klaas and Archer, 2002; Thunell et al., 2007]. However, many recent studies suggest that the $\mathrm{Si}: \mathrm{C}$ and $\mathrm{Si}: \mathrm{N}$ ratio (here we refer to organic $\mathrm{C}$ and $\mathrm{N}$ ) of biogenic producers can vary regionally as well as temporally causing a decoupling between bioSi and organic fluxes [Baines et al., 2010; Bruland, 2000; Bruland et al., 2001; Firme et al., 2003; Hutchins and Bruland, 1998]. For instance, Si:C and Si:N ratio of diatoms have been reported to change under the influence of transient iron limitation in upwelling regimes [Firme et al., 2003].

[14] Seasonal and interannual changes in Si:N export ratio at $500 \mathrm{~m}$ water depth in the GC are plotted in Figure 3 using the data published by Thunell [1998]. Overall the Si:N export ratio in the GC is very high, reaching values of 10 to 130 , compared to $<1$ in most oceanic basins except the SO and far North Pacific [Sarmiento et al., 2004]. The Si:N uptake ratio by healthy diatoms is on average 1 and reaches a value of about 3 in Fe-stressed diatoms [Brzezinski, 1985]. Therefore, even if surface production is dominated by diatoms -as it is the case in the GC- Si:N ratio of the biogenic production should remain below or about 3 . It has been shown that organic material sinking in the water column is more readily recycled than bioSi resulting in a relative enrichment in bioSi in the sediment [Ragueneau et al., 2000, 2002]. Hence, the preferential preservation of bioSi relative to organic matter must occur in the water column in order to explain the observed high Si:N export ratios.
[15] As expected on a seasonal basis, changes in the Si:N export ratios in the GC follow variations in the relative contribution of siliceous versus calcareous plankton to the total biogenic export fluxes (Figure 3). High Si:N values are observed during winter when diatoms make up to $70-95 \%$ of the biogenic export flux, and lower Si:N export ratios occur in the summer when calcareous plankton inputs increase. However, variations in Si:N (Figure 3) and Si:C (not shown) export ratio also occur on an inter-annual basis which cannot be explained by changes in the relative proportion of siliceous to calcareous fluxes. During highly productive/intense upwelling periods such as winter 1993 94, 1994-95 and 1996, the Si:N export ratios are two to three times higher than during less productive/weak upwelling winters (El Niño years 1990-1993 [Thunell, 1998]), while the relative contributions of siliceous and calcareous plankton do not vary from one winter to the other (Figure 3). In the following section we will explore which mechanism can result in a threefold increase in Si:C and Si:N export ratios during years of intense winter upwelling (as opposed to dampened winter upwelling of El Niño years).

[16] Studies have shown that the degree of preferential preservation of bioSi relative to organic compounds depends on the size and initial Si:N and Si:C ratio (silicification) of the sinking diatoms [Hutchins and Bruland, 1998; Leblanc et al., 2005]. Exported Si:N and Si:C ratios are expected to vary with the type and the degree of silicification of the diatoms. This phenomenon most probably contributes to the apparent decoupling between organic matter and bioSi export fluxes. In the next section, we explore the potential causes for a change in diatom silicification by investigating nutrient cycling in the GC. 

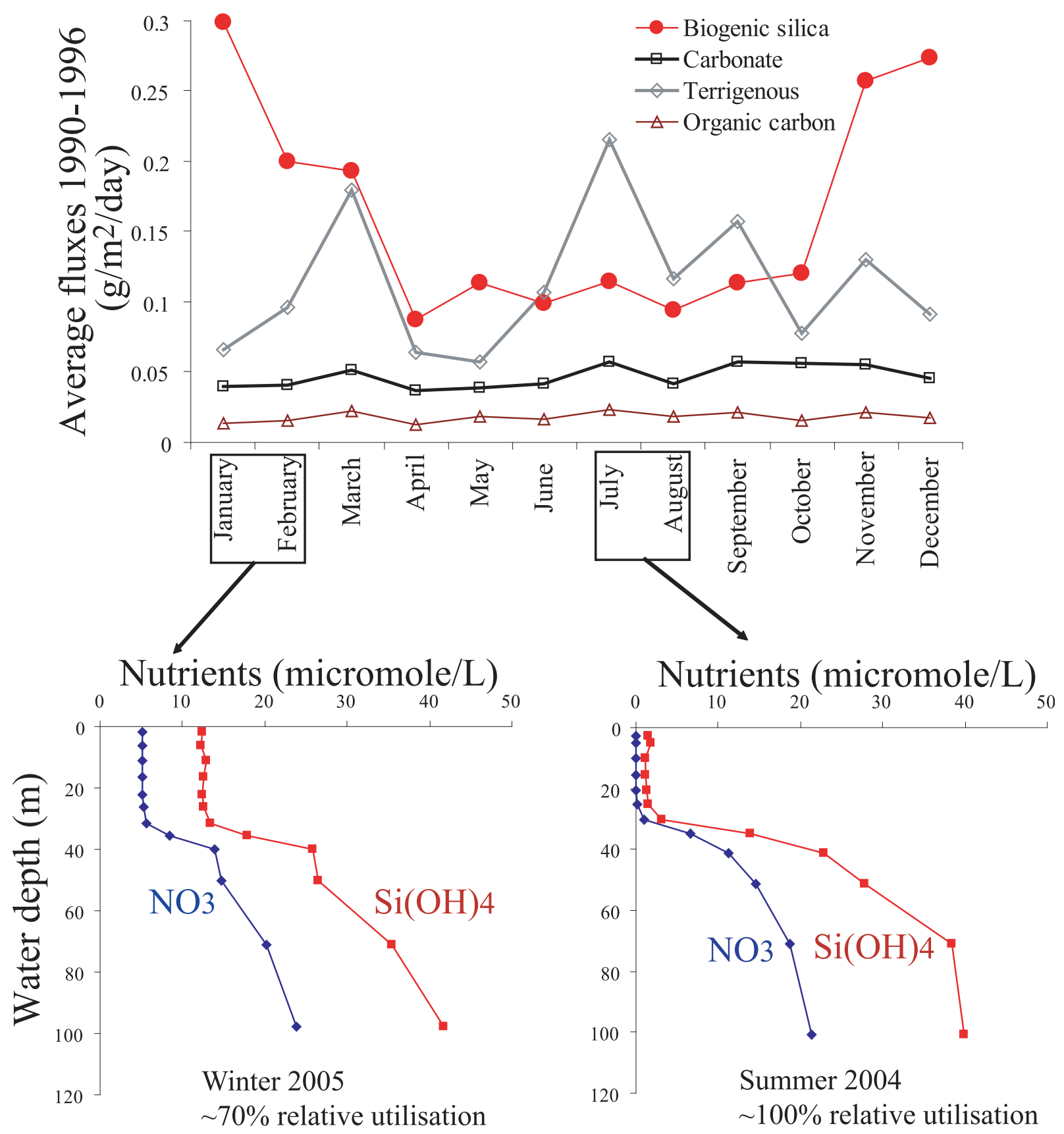

Figure 2. Seasonal changes in nutrients concentrations in the upper water column of the Guaymas Basin, GC, measured during winter 2004-2005 (upwelling season) and summer 2004 (no upwelling). These profiles represent a snapshot of the nutrient consumption by biota at a given time. El Niño conditions characterized year 2005 .

\subsection{Nutrient Concentration and Relative Utilization in the GC}

[17] Silicic acid concentration in the intermediate and subsurface waters in the Guaymas Basin is unusually high [Sarmiento et al., 2004], as shown by the annually averaged $\left[\mathrm{Si}(\mathrm{OH})_{4}\right]$ profiles from the GC compared to the open Pacific (55 $\mu \mathrm{M} / \mathrm{L}$ versus $35 \mu \mathrm{M} / \mathrm{L}$ at $200 \mathrm{~m}$ water depth, respectively; see Figure 1. Data available at http://iridl.ldeo.columbia.edu/ SOURCES/.NOAA/.NODC/.WOA01/). Nutrient distributions in the $\mathrm{GC}$ are also characterized by elevated silicate to nitrate ratio $(\mathrm{Si}(\mathrm{OH}) 4: \mathrm{NO} 3>1.8)$ in the sub-surface waters, which are much greater than the dissolved $\mathrm{Si}: \mathrm{N}$ uptake ratio for healthy diatoms growing under nutrient-replete conditions $(\sim 1)$ [Brzezinski, 1985] (Figure 1). This value is also much higher than the $\mathrm{Si}: \mathrm{N}$ export ratios of biogenic detritus which averages less than 1 for most of the ocean [Sarmiento et al., 2004, 2007]. Two mechanisms could account for the high $\mathrm{Si}(\mathrm{OH})_{4}: \mathrm{NO}_{3}^{-}$ratio: the removal of nitrate in the intermediate and subsurface water by denitrification [Altabet et al., 1999; Pride et al., 1999] and/or the build up of silicic acid in the GC through bioSi cycling and the release of $\mathrm{Si}$ from sinking detritus. Denitrification is intense in the entire eastern 


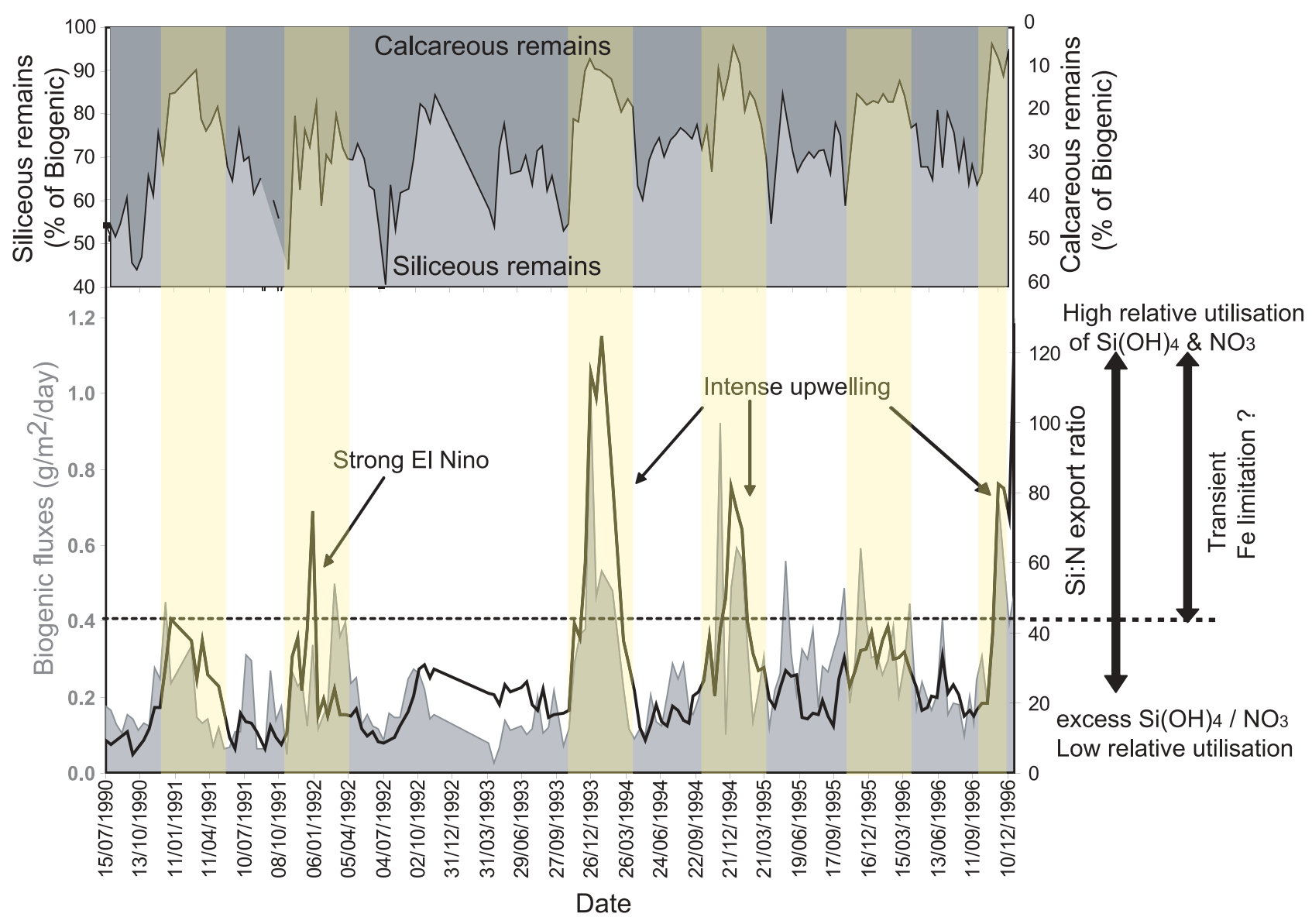

Figure 3. (bottom) Biogenic fluxes and Si:N export ratio in the sediment trap from the Guaymas Basin, GC from Thunell [1998] and (top) relative proportion of the biogenic silica and calcium carbonate remains over the total inorganic biogenic fluxes (calculated as the sum of bioSi and $\mathrm{CaCO}_{3}$ in the traps) in the same sediment trap showing the seasonal variations in the type of producers in the basin. Yellow stripes show the duration of the winter upwelling.

tropical Pacific and below the nutricline nitrate concentrations both inside and outside the GC are very similar at around $25 \mu \mathrm{M}$. Therefore, local denitrification cannot by itself explain the comparatively high $\mathrm{Si}(\mathrm{OH})_{4}: \mathrm{NO}_{3}{ }^{-}$ratio that appears to be unique to the $\mathrm{GC}$. Instead, $\mathrm{Si}(\mathrm{OH})_{4}$ concentration in the subsurface is at least $50 \%$ higher in the $\mathrm{GC}$ than in the rest of the eastern tropical Pacific, suggesting a relative enrichment in silicic acid is due to local regeneration (opal dissolution) in the subsurface and intermediate water of the GC.

[18] Annually averaged and seasonal nutrient profiles shown in Figures 1 and 2 respectively depict nutrient consumption by biota at the surface of the Guaymas Basin, close to the sediment trap and core site. In the $\mathrm{GC}\left[\mathrm{Si}(\mathrm{OH})_{4}\right]$ drops by $\sim 30 \mu$ mole/L between $75 \mathrm{~m}$ water depth and the surface due to biological uptake, whereas $\left[\mathrm{NO}_{3}{ }^{-}\right]$decreases by less than $20 \mu \mathrm{M}$ (Figure 1b). This suggests either an excess uptake of silicic acid by biota compared to nitrate, or the presence of an additional source of nitrate at the sea surface (see below). Outside the $\mathrm{GC}$, the $\mathrm{Si}(\mathrm{OH})_{4}: \mathrm{NO}_{3}{ }^{-}$uptake ratio appears to approximate 1 (Figure 1c).

[19] Figure 2 shows snapshots of nutrient profile in the Guaymas basin measured during winter 2004-2005 and summer 2004. During the winter season, nutrients concentrations are relatively high and silicic acid and nitrate are only partially depleted in the top $30 \mathrm{~m}$ of the water column due to phytoplankton uptake (Figure 2) [Sancetta, 1995]. By comparing unutilized nutrients concentrations at the sea surface and the nutrient contents in the subsurface waters during winter 2005 (Figure 2), we broadly estimate relative nutrient utilization to be around $70 \%$ for both nitrate and silicic acid. During the upwelling season the elevated $\mathrm{Si}(\mathrm{OH})_{4}: \mathrm{NO}_{3}{ }^{-}$ratio $(1.8)$ in the subsurface waters causes silicic acid to be in excess relative to nitrate at the surface. As healthy diatoms take up silicic acid and nitrate with a ratio of about $1, \mathrm{Si}(\mathrm{OH})_{4}$ relative utilization at the sea surface is expected to remain incomplete toward the end of the upwelling season while nitrate becomes rapidly exhausted by both diatoms and non siliceous primary producers. It is worth noting that winter 2004-2005 is characterized by moderate El Niño conditions and upwelling intensity and productivity in the basin is therefore moderate in comparison to what it would be during a normal or La Niña year [Sancetta, 1995; Thunell, 1998].

[20] During the summer period, the water column stratifies and any nutrient present at the sea surface from the upwelling period is completely consumed by primary producers 
[Sancetta, 1995; White et al., 2007]. Nitrogen fixation at the surface of the GC has been reported to provide around $40 \%$ of the nitrogen demand by phytoplankton during the stratified period [White et al., 2007]. Therefore, we propose that the addition of nitrate via $\mathrm{N}$-fixation allows the consumption and exhaustion of the $\mathrm{Si}(\mathrm{OH})_{4}$ remaining at the surface of the stratified water column after the upwelling period.

[21] The presence of excess silicic acid in the Gulf of California during winter months of El Niño years such as 2005 is a significant factor in explaining the inter-annual variability in bioSi fluxes and in particular Si:N export ratios in the Gulf of California (Figure 3). El Niño years with relatively moderate winter upwelling and biogenic fluxes are characterized by comparatively low Si:C and Si:N export ratios as observed in the trap material. Such conditions also lead to excess silicic acid to be present at the surface during winter months (Figure 2). In contrast, "normal" years exhibit intense upwelling, outstandingly high bioSi export rates and two to threefold higher $\mathrm{Si}: \mathrm{N}$ and $\mathrm{Si}: \mathrm{C}$ export ratios than during El Niño years. Such high Si:N and Si:C exports should lead to the depletion of silicic acid. We propose that this is caused by transient $\mathrm{Fe}$ limitation during intense upwelling events.

[22] In the central GC, Fe concentration changes with depth show a typical nutrient profile with surface depletion and enrichment at depths. Importantly, Fe is almost completely depleted in the first $50 \mathrm{~m}$ below the surface due to biological utilization [Segovia-Zavala et al., 2010]. In addition, the ratio between $\mathrm{Fe}$ and essential macronutrients in deep and subsurface waters remain below biological requirements suggesting additional sources of iron to the sea surface will be required to sustain high levels of primary productivity [Brand, 1991; Dutkiewicz et al., 2005]. These observations suggests that during intense upwelling events, the additional pool of airborne and continental shelf iron is quickly used by the rapidly growing biota, leaving surface waters of the GOC depleted in Fe relative to other nutrients [Hutchins and Bruland, 1998]. Thus, the deficit in Fe for phytoplankton growth can increase with the intensity of upwelling. This has been observed in the margins of the eastern tropical north Pacific, where transient Fe limitation occurs toward later stages of intense upwelling events and phytoplankton blooms [Firme et al., 2003; Hutchins and Bruland, 1998]. Such conditions has been shown to cause a two to threefold increase in the $\mathrm{Si}(\mathrm{OH})_{4}: \mathrm{NO}_{3}{ }^{-}$uptake ratio by diatoms [Takeda, 1998]. This in turn resulted in increased utilization of $\mathrm{Si}(\mathrm{OH})_{4}$ relative to nitrate in surface water (by a factor of 2 to 3), a high Si:N (C) export ratio, a shift toward heavily silicified fast sinking diatom frustules and better bioSi preservation [Bruland et al., 2001; Firme et al., 2003; Hutchins and Bruland, 1998; Leblanc et al., 2005; Leynaert et al., 2004]. Thus, during years of intense winter upwelling, we propose that iron stress at the surface of the GC will enhance Si uptake relative to nitrate (toward complete $\mathrm{Si}$ $(\mathrm{OH}) 4$ utilization), resulting in more silicified-diatoms and high Si:C and Si:N export ratios. Conversely, winters with related muted upwelling such as during El Niños will result in reduced iron limitation, reduced uptake of $\mathrm{Si}$, and incomplete Si utilization relative to other macronurients as documented in Figure 2 (winter, 2004-2005). This turn of events will lower the Si to N content of diatoms, and lead to lower Si to N (C) exports as documented for the GC during the El Niño years (Figure 3). Therefore, climatically induced changes in upwelling should also alter relative silicic acid utilization. Importantly, high $\mathrm{Si}: \mathrm{C}$ and $\mathrm{Si}: \mathrm{N}$ uptake ratios under $\mathrm{Fe}$ stressed conditions during intense upwelling events should deplete silicic acid in surface water relative to El Niño years of moderate upwelling and lower Si:C and Si: $\mathrm{N}$ uptake ratios.

[23] We explore below the issue of transient Fe limitation in modulating $\mathrm{Si}: \mathrm{N}(\mathrm{C})$ export ratios further in a down core record from the Gulf of California. As documented in sediment traps, biogenic (especially bioSi) fluxes during the summer period are much lower than during winter time as shown in Figures 2 and 3, and therefore relative silicic acid utilization recorded in the GC sediments is expected to be primarily a winter signal. We combine down core biogenic records $\delta^{30} \mathrm{Si}$ to explore how Si utilization efficiency has evolved with respect to upwelling variability and intensity over the last 55,000 years.

\section{Down Core Records From Core MD-02 2515}

\subsection{Biogenic Silica and Organic Carbon Contents}

[24] Currently available sedimentary records from the Gulf of California are limited to the last $17 \mathrm{ka}$ BP [Barron et al., 2005; Sancetta, 1995; Pride et al., 1999] and have documented large variability in bioSi accumulation and diatom species composition through the last Termination. Specifically, rapid declines in bioSi accumulation in this area have been found to coeval with abrupt cold events in the North Atlantic region such as Younger Dryas and Heinrich $(\mathrm{H})$ events. In Figure 4, we present new, highly resolved records of past changes in bioSi and organic carbon accumulations in the Guaymas Basin between 6.8 and $55 \mathrm{ka}$ BP from Core MD 02-2515. These illustrate that the contribution of bioSi in the sediment is as high as $55 \%$, decreasing abruptly to $5-15 \%$ during the Younger Dryas and $\mathrm{H} 1$ to H4 (Figure 4). It is difficult to precisely determine accumulation rates in Core MD $02-2515$ because the ${ }^{230} \mathrm{Th}$ normalization technique is not well suited to rapidly accumulating coastal margin sediments [Francois et al., 2004]. Nevertheless, Core MD 02-2515 is well dated $\left(28\right.$ AMS $^{14} \mathrm{C}$ dates over $65 \mathrm{~m}$ ) which allows us to estimate sedimentation rates in the basin with high confidence (Figure 4). Both bioSi \% and sedimentation rates indicate that bioSi accumulation decreased sharply during $\mathrm{YD}$ and $\mathrm{H}$ events (Figure 4), in agreement with earlier works [Pride et al., 1999]. The new record confirms findings from existing records spanning the last 17 ka B.P. [Barron et al., 2004, 2005; Pride et al., 1999; Sancetta, 1995] and documents that the abrupt changes in bioSi accumulation during Heinrich events persisted throughout the last glacial period and Marine Isotope Stage 3. The general decline in opal and organic carbon accumulation during Marine Isotope Stage 2 and 3 relative to the Holocene seen in Figure 3 has been reported in previous studies in this margin outside the GOC [Ganeshram and Pedersen, 1998]. Beyond 35 kyr, dating uncertainties of up to $3 \mathrm{ka}$ make it difficult to verify the persistence of this relationship for H5 (Figure 4).

[25] Sediment traps studies have shown that seasonal changes in opal fluxes are controlled by the intensity of the upwelling [Sancetta, 1995; Thunell, 1998] and as a result the lower bioSi \% during cold periods may imply reduced 


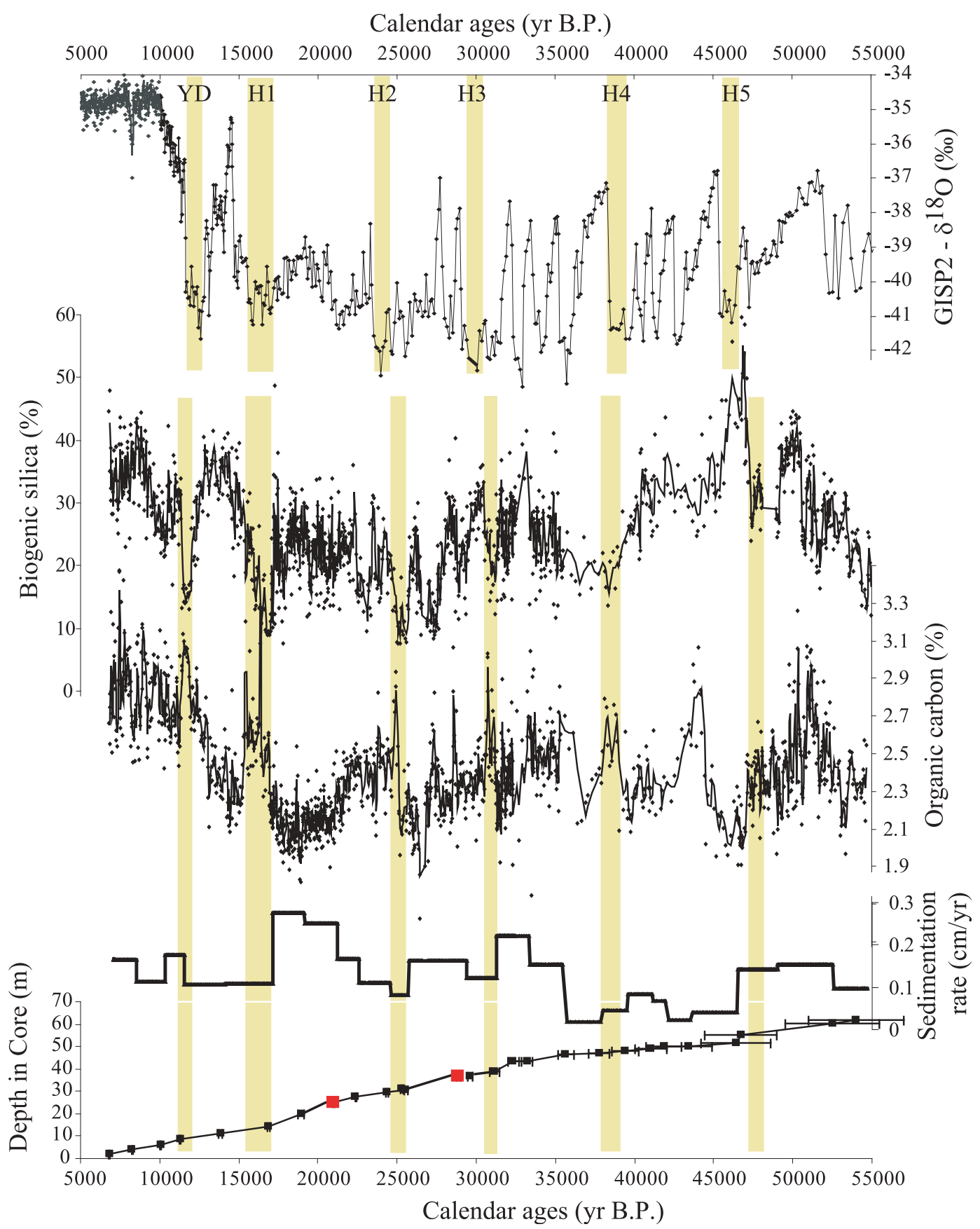

Figure 4. From top to bottom, GRIP $\delta^{18} \mathrm{O}$ record from Greenland ice core (\%) [Blunier et al., 1998] compared to biogenic opal (\%), organic carbon (Corg, \%) and sedimentation rates in core MD 02-2515. Sedimentation rates in core MD 02-2515 were calculated from the radiocarbon dates and age-depth diagram shown in the bottom panel, which illustrates the 28 radiocarbon dates used to construct the age model. Red dots correspond to the paired planktonic foraminifera- and organic carbon- ${ }^{14} \mathrm{C}$ dates. Yellow stripes identify Heinrich events.

upwelling and opal fluxes. This is supported by new temperature proxy data from Core MD 02-2515 [McClymont et al., 2012], which suggest that the upper water column was more stratified during the YD and H1 in the Guaymas basin when opal production decreased. Therefore, sedimentary bioSi\% declines are interpreted as reflecting reduced upwelling intensity in the basin during the YD and $\mathrm{H}$ events as suggested by earlier workers.
[26] Although diatoms represent most of the primary production in this region [Nelson et al., 1995], the organic carbon record does not correlate with the variations in bioSi at glacialinterglacial and millennial timescales (Figure 4). This confirms that the decoupling between organic carbon and bioSi fluxes observed in the sediment traps [Thunell et al., 1993; Thunell, 1998] (Figure 2) also persisted in the past. It is worth noting that sedimentary Si:N and Si:C ratio during the Holocene 


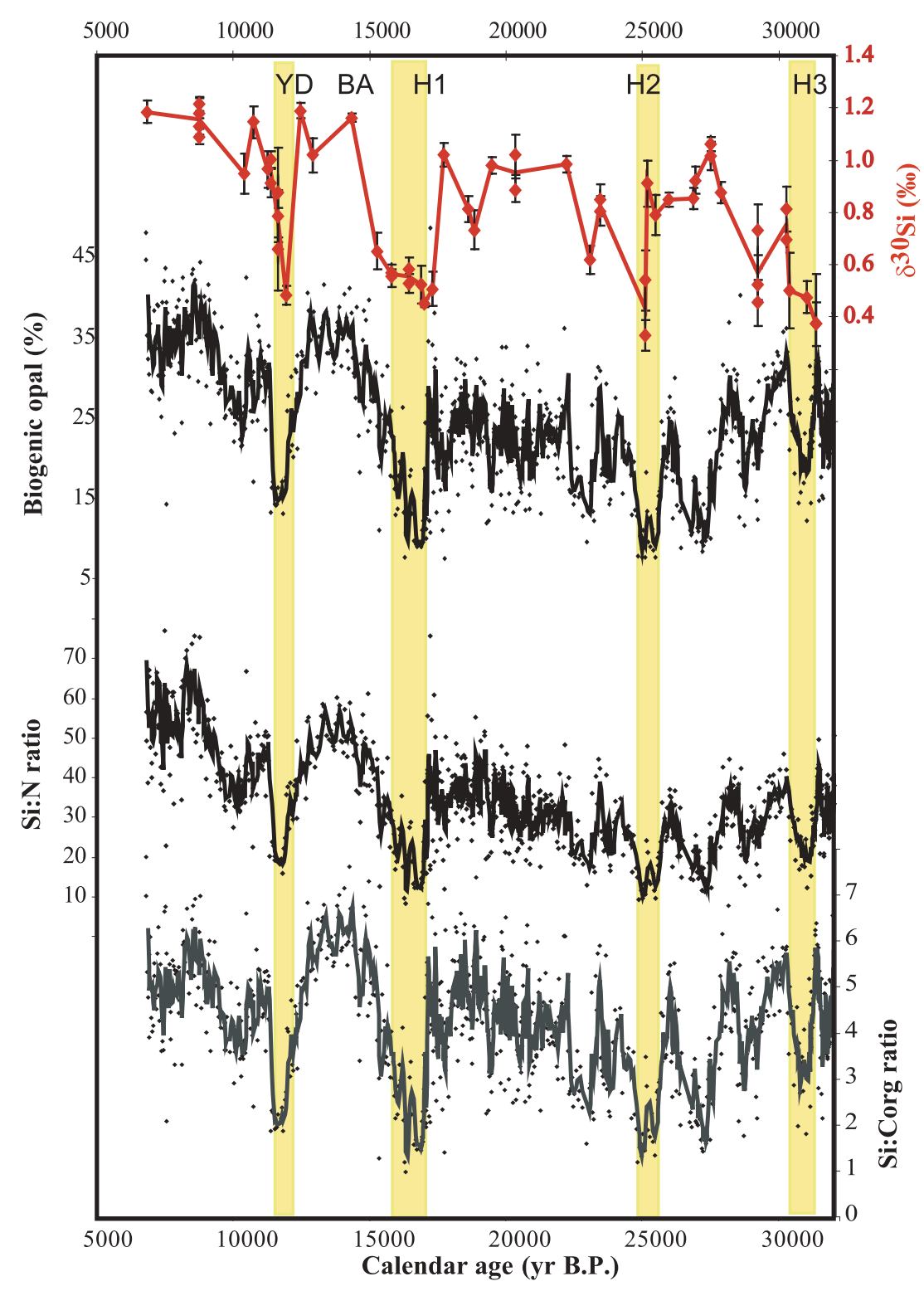

Figure 5. From top to bottom, silicon isotope ratio from sedimentary diatoms (\%), biogenic opal content (\%) and sedimentary Si:N and Si:C (organic) ratio in core MD 02-2515. Stripes identify Heinrich events.

and B/A (Figure 5) are very similar to the values seen in the modern sediment trap sediment collected during intense winter upwelling (section 3.1 and Figure 3) but that they sharply declines during YD and $\mathrm{H} 1-3$ events. As proposed earlier, we explain this decoupling between organic $\mathrm{C} \%$ and bioSi $\%$ as reflecting dilution of the organic matter by the opal fraction due to preferential opal preservation as well as potential changes in the $\mathrm{Si}: \mathrm{C}(\mathrm{N})$ ratio of the diatoms under the influence of variable iron stress. Specifically, the question we address is whether the declines in bioSi and Si:C and Si:N ratios during $\mathrm{YD}$ and $\mathrm{H} 1-3$ events were accompanied by excess silicic acid in surface waters.

\subsection{The Silicon Isotope Record}

[27] Past variations in bioSi accumulation from the Gulf of California have been interpreted as resulting mainly from changes in silicic acid supply through upwelling [Barron et al., 2004, 2005; Pride et al., 1999]. However, the role of variable degree of silicic acid utilization in impacting bioSi records has never been considered in upwelling regions. The use of silicon isotopes in water samples, diatoms or other siliceous producers has been shown to provide direct information on silicic acid utilization in surface waters [Brzezinski et al., 2002; de la Rocha et al., 1997, 1998; Reynolds et al., 2006a]. This geochemical tool relies on the fact that diatoms favor the lighter isotope during uptake [de la Rocha et al., 1997]. Hence, diatom $\delta^{30} \mathrm{Si}$ increases with increased silicic acid utilization efficiency in the surface waters. When all the silicic acid is utilized, the average sedimentary diatom- $\delta^{30} \mathrm{Si}$ value is equal to the initial isotopic signal of the source silicic acid following Rayleigh fractionation kinetics [de la Rocha et al., 1997].

[28] The diatom- $\delta^{30} \mathrm{Si}$ record from Core MD 02-2515 spanning the last $30 \mathrm{ka}$ is presented in Figure 5. The record resolves millennial-scale events associated with the YD and $\mathrm{H} 1-3$. The $\delta^{30} \mathrm{Si}$ signal varies between $0.45 \%$ and $1.2 \%$ 
with higher values occurring during the Holocene and Bølling-Allerød (B/A). The most striking feature of this record is the low values documented during the $\mathrm{YD}, \mathrm{H} 1, \mathrm{H} 2$ and $\mathrm{H} 3$. The $\delta^{30} \mathrm{Si}$ record seems to parallel bioSi \% with low $\delta^{30} \mathrm{Si}$ when bioSi accumulation is low in the Guaymas Basin (Figure 4).

[29] In addition, a more subtle glacial-interglacial difference also exists where the $\delta^{30} \mathrm{Si}$ values are slightly lower (by about $0.2 \%$, ) during the Last Glacial Maximum and Stage 3 relative to the early Holocene. The potential causes and implications of these findings are discussed in the following sections.

\section{Orbital and Millennial-Scale Changes in Silicic Acid Cycling in the GC}

\subsection{The Holocene and Bølling-Allerød}

[30] The water masses in the GC are sourced from the subtropical Pacific at subsurface depths and from the North Pacific Intermediate Waters at depths $>600 \mathrm{~m}$ [Bray, 1988]. The $\delta^{30} \mathrm{Si}$ values of dissolved silicic acid supplied through these water masses are estimated to be around 1.3\% [de la Rocha et al., 2000; Reynolds et al., 2006a]. During the mid-early Holocene and the $\mathrm{B} / \mathrm{A}$, the $\delta^{30} \mathrm{Si}$ signal in Core MD $02-2515$ is $\sim 1.2 \%$. Therefore, this value approximates the isotopic signature of the modern silicic acid source. This suggests that the relative utilization of silicic acid was nearly complete during these time intervals. As shown by the nutrient profiles (Figures 1 and 2), silicic acid is present in excess relative to nitrate (ratios of 1.8) in modern subsurface waters. As healthy diatoms in the environment are presumed to take up nitrate and silicic acid in 1:1 proportions, unutilized $\mathrm{Si}(\mathrm{OH})_{4}$ is expected in the surface waters of the Gulf of California once the supply of nitrate is depleted by the phytoplankton. This generation of excess $\mathrm{Si}(\mathrm{OH})_{4}$ is expected to be further enhanced given that non-siliceous plankton also consume nitrate in the surface layer. Therefore, a $\delta^{30} \mathrm{Si}$ signal of $1.2 \%$ indicative of complete $\mathrm{Si}(\mathrm{OH})_{4}$ utilization argues for a $\mathrm{Si}(\mathrm{OH})_{4}: \mathrm{NO}_{3}$ uptake ratio of $>1$ by diatoms during the Holocene and B/A. Such preferential utilization of silicic acid is characteristic of diatom growth under Fe-limited conditions [Hutchins and Bruland, 1998].

[31] Atmospheric conditions in the GC during the late, mid and early Holocene are reported to have been favorable for intense upwelling and high diatom productivity during winter time [e.g., Sancetta, 1995]. Northwesterly winds increased to a maximum during the late Holocene, resulting in very high upwelling rates. Conditions during the $\mathrm{B} / \mathrm{A}$ were similar to the Holocene with intense upwelling, high productivity and elevated bioSi accumulation [Barron et al., 2005]. Our sediment trap data reveal that times of intense upwelling are characterized by high $\mathrm{Si} / \mathrm{C}$ and $\mathrm{Si} / \mathrm{N}$ ratios of settling detritus and increased preferential preservation of bioSi relative to organic matter (Figure 3). We attribute this trend to transient iron deficiency that can enhance silicic acid uptake by diatoms relative to other macronutrients. Our records from core MD 02-2515 suggest that such a scenario is compatible with the occurrence of episodic but frequent Fe limitation during the Holocene and B/A leading to nearly complete silicic acid utilization, high bioSi accumulation and increased preferential preservation of bioSi relative to organic compounds (Figure 5).
[32] In addition, modern nutrient profiles collected during winter 2005 show that $\mathrm{Si}(\mathrm{OH})_{4}$ utilization was probably incomplete during El Niño years (weak upwelling). Therefore our $\delta^{30} \mathrm{Si}$ record is consistent with the proposition that El Niño events were infrequent and/or less intense during the Holocene and B/A compared to other climatic periods [Barron et al., 2004; Sancetta, 1995].

\subsection{The Last Glacial Period}

[33] During the last Glacial (MIS 2 and 3, Heinrich events excluded), sedimentary $\delta^{30} \mathrm{Si}$ is slightly lower $(0.2 \%$ at most) than during the Holocene and B/A. Before directly interpreting the $\delta^{30} \mathrm{Si}$ variations as reflecting past changes in the degree of silicic acid utilization by diatoms, it is important to consider what other processes could cause changes in the isotopic composition of the silicic acid source through time [de la Rocha and Bickle, 2005; de la Rocha et al., 1997; Pichevin et al., 2007; Reynolds et al., 2006c]. In the western and eastern North Pacific ocean, $\mathrm{Si}(\mathrm{OH})_{4}-\delta^{30} \mathrm{Si}$ of the subsurface water is about $1.2-1.3 \%$ today, and around $1.1 \pm$ $0.3 \%$ in the whole ocean [de la Rocha et al., 2000; Reynolds et al., 2006a] -although it appears to be slightly heavier in the Subantarctic thermocline [Beucher et al., 2007, 2008; Cardinal et al., 2005]. Therefore, potential circulation changes during climatic transitions could result in small variations of the $\delta^{30} \mathrm{Si}$ of the marine silicic acid source. In addition, decreased silicic acid utilization in high-nutrient low-chlorophyll regions like the SO and Equatorial Pacific have been reported during the Last Glacial Maximum [Brzezinski et al., 2002; Pichevin et al., 2009]. This could have resulted in the leakage of isotopically lighter silicic acid to adjoining oceans, thereby driving the overall marine silicic acid source signal toward lighter $\delta^{30} \mathrm{Si}$. However, this hypothesis cannot account for the lower $\delta^{30} \mathrm{Si}$ measured in Core MD 02-2515 during Marine Isotope Stage 3.

[34] Changes in the continental input of $\mathrm{Si}(\mathrm{OH})_{4}$ on orbital timescales can impact global and local $\delta^{30} \mathrm{Si}$ signatures. On average the $\delta^{30} \mathrm{Si}$ signal of riverine sources is expected to be around 0.8\%o [de la Rocha et al., 2000]. Box model results show that doubling or halving of the riverine $\mathrm{Si}(\mathrm{OH})_{4}$ input to the ocean over tens of thousands of years have a minor impact on the $\mathrm{Si}$ isotopes of the whole ocean silicic acid and marine diatoms [de la Rocha and Bickle, 2005; Georg et al., 2009]. This occurrence would not result in a noticeable change in the global $\mathrm{Si}(\mathrm{OH})_{4}-\delta^{30} \mathrm{Si}$ at orbital timescales. And, considering the large residence time of $\mathrm{Si}$ in the ocean (in the order of 10,000 years; [DeMaster, 2002]), it would have no impact at short time scales either. Locally, however, one might envision that a sharp increase in the input of isotopically lighter fluvial $\mathrm{Si}(\mathrm{OH})_{4}$ to the $\mathrm{GC}$ under the influence of drastic climate shifts could have a noticeable impact on the silicic acid $\delta^{30} \mathrm{Si}$ in the surface water of the basin. Today, Colorado river is the main source of riverine $\mathrm{Si}(\mathrm{OH})_{4}$ to the Gulf of California. Climatic conditions in the Colorado river catchment area are reported to have been more humid during Heinrich events and the last glacial period than during the Holocene [Wagner et al., 2010] potentially causing the source $\delta^{30} \mathrm{Si}$ to drop by as much as $0.2 \%$.

[35] In summary, the slight decrease in the silicon isotope signal observed during the last glacial period compared to the Holocene and B/A could be either due to: (1) increased 


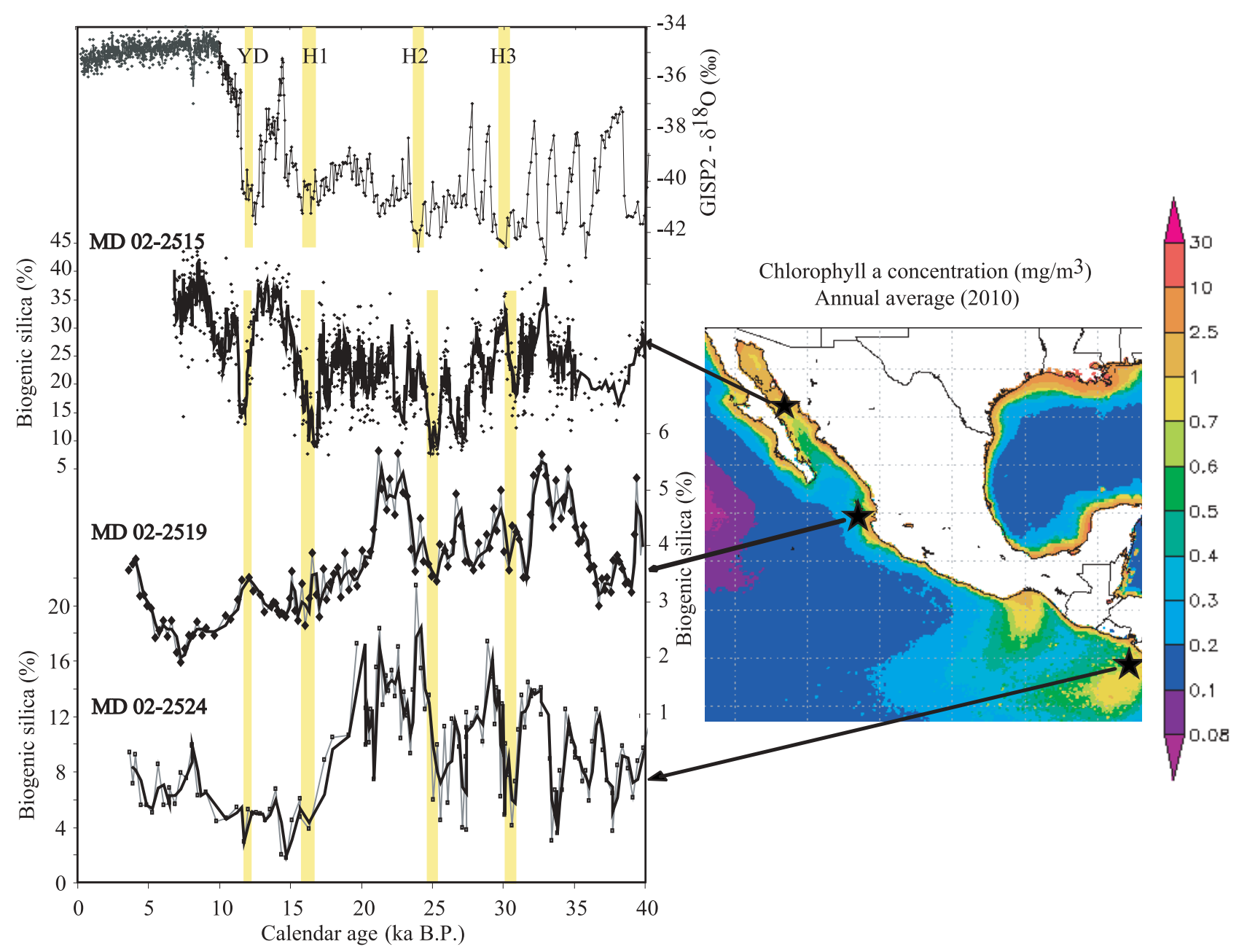

Figure 6. From top to bottom, GRIP $\delta^{18} \mathrm{O}(\%)$ [Blunier et al., 1998] record from Greenland ice core compared to biogenic silica (\%) in Core MD 02-2515, Core MD 02-2519 and Core MD 02-2524 from the Eastern Tropical North Pacific [Arellano-Torres et al., 2011]. Yellow stripes identify Heinrich events. Colors on the map represent chlorophyll a concentrations in the surface ocean from http://gdata1.sci.gsfc. nasa.gov/ and evidence upwelling zones. Core locations are shown with black stars.

riverine supply of "light" silicic acid to the GC at a time when the regional climate was relatively more humid; (2) changes in the marine silicic acid source signal toward lighter $\delta^{30} \mathrm{Si}$; or (3) incomplete $\mathrm{Si}(\mathrm{OH})_{4}$ relative utilization in the GC. While it is impossible to untangle the causes of the small $\delta^{30} \mathrm{Si}$ shift between the LGM and the Holocene, it is worth mentioning that both hypotheses (2) and (3) are compatible with the recently proposed scenario whereby silicic acid utilization decreased in iron-limited regions of the ocean such as the SO and Eastern Equatorial Pacific during the LGM. In such regions, relaxation of the iron stress on producers is thought to have triggered both an increase in $\mathrm{Si}(\mathrm{OH})_{4}$ availability [Brzezinski et al., 2002; Pichevin et al., 2009] and a potential decrease the $\mathrm{Si}(\mathrm{OH})_{4}-$ $\delta^{30} \mathrm{Si}$ signal in the low latitudes (Figure 6) [Arellano-Torres et al., 2011; Pichevin et al., 2009].

\subsection{Heinrich Events}

[36] Sharp decreases in bioSi accumulation and the Si isotope values coincide with the YD and $\mathrm{H}$ events. The $\delta^{30} \mathrm{Si}$ falls to $0.45-0.6 \%$ during $\mathrm{H}$ events from $1 \%$ during the last glacial and $1.2 \%$ during the early Holocene and B/A. Such severe and abrupt declines cannot be explained by changes in the marine source of silicic acid or by a global increase in the continental silicic acid input (see section 5.2). Fluvial discharge of isotopically lighter $\mathrm{Si}(\mathrm{OH})_{4}$ by the Colorado river can also be ruled out as a cause for the sharp decreases in $\delta^{30} \mathrm{Si}$ during Heinrich events, considering that Wagner et al. [2010] showed that West American climate was not significantly wetter during such times compared to the last glacial period. Low sedimentation rates recorded in Core MD 02-2515 during $\mathrm{H}$ events also point to low terrigenous inputs to the basin relative to the last glacial period (Figure 5). Thus, potential variations in the source $\mathrm{Si}(\mathrm{OH})_{4}-\delta^{30} \mathrm{Si}$ alone cannot account for the very large $(>0.5 \%)$ shift in the $\delta^{30} \mathrm{Si}$ signal recorded in Core MD 02-2515 during H events. Likewise, variations in the composition of the diatom species assemblage cannot explain the observed $\delta^{30} \mathrm{Si}$ variations recorded in the $\mathrm{GC}$, because studies have shown that there is no or little difference in the silicon isotopic fractionation between different species [de la Rocha et al., 1997]. Admittedly, however, such studies are few, and require confirmation. More 
importantly, irrespective of hypothetical differences in the diatom-species specific fractionation factor, complete $\mathrm{Si}$ utilization results in a sedimentary $\delta^{30} \mathrm{Si}$ signal equal to the silicic acid source signal (1.3\%), while incomplete utilization is recorded in the sediment as lighter $\delta^{30} \mathrm{Si}$ values. Therefore, the large decreases in $\delta^{30} \mathrm{Si}$ recorded in Core MD 02-2515 cannot be simply caused by ecological shifts in diatom species or changes in riverine inputs but rather indicate drastic reductions in the relative silicic acid utilization by diatoms during $\mathrm{H}$ events locally with in the Gulf.

[37] Several previous studies using a range of proxy indicators have suggested that upwelling and diatom production were reduced during colder phases of millennial scale cycles in this locality [Barron et al., 2004, 2005; Cheshire et al., 2005; Sancetta, 1995, McClymont et al., 2012]. Our records therefore suggest that during times of weakened upwelling and low diatom production, silicic acid was available in the surface ocean and remained unutilized. This situation is in agreement with the modern observation that silicic acid is in excess in the subsurface water compared to nitrate and remains unused at the sea surface during winters of moderate upwelling (El Niño) and in the absence of iron stress (section 3.1). We therefore propose that incomplete silicic acid utilization during $\mathrm{H}$ events is caused by the decrease in upwelling intensity. The prevalence or increased intensity and/or frequency of El Niño conditions in the eastern tropical Pacific could result in such conditions. This is supported by existing studies based on diatom counts in the GC [Barron et al., 2005; Sancetta, 1995].

[38] Interestingly, drastically reduced denitrification rates have been documented during $\mathrm{H}$ events in the basin [Pride et al., 1999]. Denitrification removes nitrate from the subsurface and intermediate waters. Hence, decreased denitrification locally would have increased the availability of nitrate relative to other nutrients compared to today and this would have decreased the $\mathrm{Si}(\mathrm{OH})_{4}: \mathrm{NO}_{3}$ ratio in the Gulf of California subsurface waters during $\mathrm{H}$ events. This in turn should have allowed greater relative utilization of silicic acid at these times, which is not what we observe. Increased nitrate availability at these times could have also promoted productivity of non-siliceous phytoplankton.

[39] We calculated relative silicic acid utilization during $\mathrm{H}$ events by using both the Rayleigh fractionation model and the steady state model and assuming the initial $\delta^{30} \mathrm{Si}$ to be between 1 (glacial lowest estimate -section 5.2) and 1.3\%o (modern value) [Beucher et al., 2008; de la Rocha et al., 1997]. Relative Si utilization during $\mathrm{H}$ events was between 20 and $50 \%$, much lower than the estimated $70 \%$ today (section 3.1).

[40] Records from other locations in the Eastern Tropical North Pacific (ETNP) show similar patterns of reduced bioSi\% and accumulation during $\mathrm{H}$ events (Figure 6) as well as reduced organic carbon accumulation [e.g., ArellanoTorres et al., 2011; Hendy et al., 2004]. Such a uniform decline in upwelling-stimulated productivity in the region is compatible with more intense or prevalent El Niño conditions in the Eastern Tropical Pacific during cold spells as proposed in earlier studies [Koutavas et al., 2002; Sancetta, 1995; Stott, 2002]. There is considerable debate surrounding the manifestation of ENSO dynamics in the context of changing ocean-atmosphere mean state across climatic transitions [e.g., Pena et al., 2008; Prange et al.,
2010]. However, irrespective of mean state changes, our study together with earlier works clearly points to generally reduced upwelling in the entire eastern Pacific during $\mathrm{H}$ events, a feature characteristic of El Niño conditions. Thus, for the first time, a drastic effect of regionally reduced upwelling is shown not only on primary productivity but also on marine silicon cycling at the millennial time scale.

\section{Conclusions and Implications}

[41] We suggest that strong links exist between upwelling strength, (transient) Fe limitation and marine Si biogeochemical cycling in coastal upwelling regions. Transient iron limitation has been observed in coastal upwelling area in the region toward the end of intense upwelling episodes [Firme et al., 2003; Hutchins and Bruland, 1998]. Our study documents the dramatic impact of this phenomenon on $\mathrm{Si}$ burial in these regions. We suggest that transient Fe limitation under conditions of increased upwelling intensity leads to near complete silicic acid utilization (high $\delta^{30} \mathrm{Si}$ ) and enhanced opal burial. Decreased upwelling strength during $\mathrm{H}$ events appears to lead to the relaxation of Fe limitation resulting in a decline in the relative utilization of silicic acid and opal burial. This has several important implications. First, our study illustrates that Fe deficiency is not only a function of insufficient iron supply as was ascribed to open ocean (like in the SO) settings but can be also effected through increased upwelling which increases $\mathrm{Fe}$ demand during phytoplankton growth. Second, because Si utilization and silicification increase under conditions of transient $\mathrm{Fe}$ limitation the relationship between upwelling and opal burial is nonlinear in these localities. This explains why some coastal upwelling regions such as the Gulf of California are more efficient sinks of biogenic Si than the others in the modern ocean [DeMaster, 2002]. Third, we suggest that high opal burial in the GC which is referred to as a modern analogue for the formation of diatomaceous facies in geological records [Calvert, 1966] is at least partly the result of the prevalence of transient $\mathrm{Fe}$ limitation.

[42] Finally, the uniform decrease in bioSi burial in the eastern Tropical Pacific during $\mathrm{H}$ events (Figure 6) [Arellano-Torres et al., 2011] due to generally reduced upwelling shows that climate-related changes in upwelling dynamics can have a drastic impact on the sedimentary sink of Si on millennial timescales. Therefore we propose that upwelling dynamics, in combination with (sporadic) Fe limitation, have the potential to determine the distribution and availability of silicic acid even over short time intervals.

[43] Acknowledgments. This research has been funded by awards from the Natural Environment Research Council (NERC) to R.G. and L.E.P. and from the U.S. National Science Foundation (OCE- 0726422) to F.P. The cores were retrieved by the R/V Marion Dusfresne through the IMAGES IV program. The authors are grateful to Yvon Balut and his team on board the Marion Dusfresne, and thank W. Geibert and A. Chang for thoughtful discussions.

\section{References}

Altabet, M. A., et al. (1999), The nitrogen isotope biogeochemistry of sinking particles from the margin of the Eastern North Pacific, Deep Sea Res., Part I, 46, 655-679, doi:10.1016/S0967-0637(98)00084-3.

Archer, D., and E. Maier-reimer (1994), Effect of deep-sea sedimentary calcite preservation on atmospheric $\mathrm{CO}_{2}$ concentration, Nature, 367, 260-263, doi:10.1038/367260a0. 
Arellano-Torres, E., et al. (2011), High-resolution opal records from the eastern tropical Pacific provide evidence for silicic acid leakage from HNLC regions during glacial periods, Quat. Sci. Rev., 30, 1112-1121, doi:10.1016/j.quascirev.2011.02.002.

Armstrong, R. A., et al. (2001), A new, mechanistic model for organic carbon fluxes in the ocean based on the quantitative association of POC with ballast minerals, Deep Sea Res., Part II, 49, 219-236, doi:10.1016/ S0967-0645(01)00101-1.

Baines, S. B., B. S. Twining, M. A. Brzezinski, D. M. Nelson, and N. S. Fisher (2010), Causes and biogeochemical implications of regional differences in silicification of marine diatoms, Global Biogeochem. Cycles, 24, GB4031, doi:10.1029/2010GB003856.

Bard, E., et al. (2004), Radiocarbon calibration beyond 20,000 C-14 yr BP by means of planktonic foraminifera of the Iberian Margin, Quat. Res. 61, 204-214, doi:10.1016/j.yqres.2003.11.006.

Barron, J. A., et al. (2004), High resolution paleoceanography of the Guaymas Basin, Gulf of California, during the past 15000 years, Mar Micropaleontol., 50, 185-207, doi:10.1016/S0377-8398(03)00071-9.

Barron, J. A., et al. (2005), Paleoceanographic history of the Guaymas Basin, Gulf of California, during the past 15,000 years based on diatoms, silicoflagellates, and biogenic sediments, Mar. Micropaleontol., 56, 81-102, doi:10.1016/j.marmicro.2005.04.001.

Berger, R., et al. (1966), Radiocarbon content of marine shells from the California and Mexican west coast, Science, 153, 864-866, doi:10.1126 science.153.3738.864

Beucher, C. P., M. A. Brzezinski, and X. Crosta (2007), Silicic acid dynamics in the glacial sub-Antarctic: Implications for the silicic acid leakage hypothesis, Global Biogeochem. Cycles, 21, GB3015, doi:10.1029/ 2006GB002746.

Beucher, C. P., et al. (2008), Sources and biological fractionation of Silicon isotopes in the Eastern Equatorial Pacific, Geochim. Cosmochim. Acta, 72,3063-3073, doi:10.1016/j.gca.2008.04.021.

Blunier, T., et al. (1998), Asynchrony of Antarctic and Greenland climate change during the last glacial period, Nature, 394, 739-743, doi:10.1038/ 29447.

Brand, L. E. (1991), Minimum iron requirements of marine-phytoplankton and the implications for the biogeochemical control of new production, Limnol. Oceanogr., 36, 1756-1771, doi:10.4319/1o.1991.36.8.1756.

Bray, N. A. (1988), Water mass formation in the Gulf of California, J. Geophys. Res., 93(C8), 9223-9240, doi:10.1029/JC093iC08p09223.

Broecker, W. S., and T. H. Peng (1984), Tracers in the Sea, 690 pp., Eldigio Press, New York.

Bruland, K. W. (2000), Iron in coastal upwelling regimes off central California: Implications for extensive blooms of large diatoms, Abstr. Pap. Am. Chem. Soc., 219, U866.

Bruland, K. W., et al. (2001), Iron and macronutrients in California coastal upwelling regimes: Implications for diatom blooms, Limnol. Oceanogr., 46, 1661-1674, doi:10.4319/1o.2001.46.7.1661

Brzezinski, M. A. (1985), The Si-C-N Ratio of Marine Diatoms Interspecific Variability and the Effect of Some Environmental Variables, J. Phycol., 21, 347-357, doi:10.1111/j.0022-3646.1985.00347.x.

Brzezinski, M. A., C. J. Pride, V. M. Franck, D. M. Sigman, J. L. Sarmiento, K. Matsumoto, N. Gruber, G. H. Rau, and K. H. Coale (2002), A switch from $\mathrm{Si}(\mathrm{OH})_{4}$ to $\mathrm{NO}_{3}{ }^{-}$depletion in the glacial Southern Ocean, Geophys. Res. Lett., 29(12), 1564, doi:10.1029/2001GL014349.

Calvert, S. E. (1966), Origin of diatom-rich varved sediments from Gulf of California, J. Geol., 74, 546, doi:10.1086/627188.

Cardinal, D., L. Y. Alleman, F. Dehairs, N. Savoye, T. W. Trull, and L. André (2005), Relevance of silicon isotopes to Si-nutrient utilization and Si-source assessment in Antarctic waters, Global Biogeochem. Cycles, 19, GB2007, doi:10.1029/2004GB002364.

Chai, F., et al. (2002), One-dimensional ecosystem model of the equatorial Pacific upwelling system. Part I: Model development and silicon and nitrogen cycle, Deep Sea Res., Part II, 49, 2713-2745, doi:10.1016/ S0967-0645(02)00055-3.

Cheshire, H., et al. (2005), Late Quaternary climate change record from two long sediment cores from Guaymas Basin, Gulf of California, J. Quat. Sci., 20, 457-469, doi:10.1002/jqs.944.

de la Rocha, C. L., and M. J. Bickle (2005), Sensitivity of silicon isotopes to whole-ocean changes in the silica cycle, Mar. Geol., 217, 267-282, doi:10.1016/j.margeo.2004.11.016.

de la Rocha, C. L., et al. (1997), Fractionation of silicon isotopes by marine diatoms during biogenic silica formation, Geochim. Cosmochim. Acta, 61, 5051-5056, doi:10.1016/S0016-7037(97)00300-1.

de la Rocha, C. L., et al. (1998), Silicon-isotope composition of diatoms as an indicator of past oceanic change, Nature, 395, 680-683, doi:10.1038/ 27174 de la Rocha, C. L., et al. (2000), A first look at the distribution of the stable isotopes of silicon in natural waters, Geochim. Cosmochim. Acta, 64 2467-2477, doi:10.1016/S0016-7037(00)00373-2.

DeMaster, D. J. (2002), The accumulation and cycling of biogenic silica in the Southern Ocean: Revisiting the marine silica budget, Deep Sea Res., Part II, 49, 3155-3167, doi:10.1016/S0967-0645(02)00076-0.

Dugdale, R. C., and F. P. Wilkerson (1998), Silicate regulation of new production in the equatorial Pacific upwelling, Nature, 391, 270-273, doi: $10.1038 / 34630$.

Dugdale, R. C., et al. (1995), The Role of a Silicate Pump in Driving New Production, Deep Sea Res., Part I, 42, 697-719, doi:10.1016/0967-0637 (95)00015-X

Dutkiewicz, S., M. J. Follows, and P. Parekh (2005), Interactions of the iron and phosphorus cycles: A three-dimensional model study, Global Biogeochem. Cycles, 19, GB1021, doi:10.1029/2004GB002342.

Firme, G. F., E. L. Rue, D. A. Weeks, K. W. Bruland, and D. A. Hutchins (2003), Spatial and temporal variability in phytoplankton iron limitation along the California coast and consequences for $\mathrm{Si}, \mathrm{N}$, and $\mathrm{C}$ biogeochemistry, Global Biogeochem. Cycles, 17(1), 1016, doi:10.1029/2001GB001824. Francois, R., S. Honjo, R. Krishfield, and S. Manganini (2002), Factors controlling the flux of organic carbon to the bathypelagic zone of the ocean, Global Biogeochem. Cycles, 16(4), 1087, doi:10.1029/2001GB001722.

Francois, R., M. Frank, M. M. Rutgers van der Loeff, and M. P. Bacon (2004), ${ }^{230} \mathrm{Th}$ normalization: An essential tool for interpreting sedimentary fluxes during the late Quaternary, Paleoceanography, 19, PA1018, doi:10.1029/2003PA000939.

Ganeshram, R. S., and T. F. Pedersen (1998), Glacial-interglacial variability in upwelling and bioproductivity off NW Mexico: Implications for quaternary paleoclimate, Paleoceanography, 13, 634-645, doi:10.1029/ 98PA02508.

Ganeshram, R. S., et al. (1995), Large changes in oceanic nutrient inventories from glacial to interglacial periods, Nature, 376, 755-758, doi: $10.1038 / 376755 \mathrm{a} 0$

Georg, R. B., et al. (2009), Silicon fluxes and isotope composition of direct groundwater discharge into the Bay of Bengal and the effect on the global ocean silicon isotope budget, Earth Planet. Sci. Lett., 283, 67-74, doi:10.1016/j.epsl.2009.03.041.

Harrison, K. G. (2000), Role of increased marine silica input on paleo- $p \mathrm{CO}_{2}$ levels, Paleoceanography, 15, 292-298, doi:10.1029/1999PA000427.

Hendy, I. L., T. F. Pedersen, J. P. Kennett, and R. Tada (2004), Intermittent existence of a southern Californian upwelling cell during submillennial climate change of the last $60 \mathrm{kyr}$, Paleoceanography, 19, PA3007, doi:10.1029/2003PA000965.

Hutchins, D. A., and K. W. Bruland (1998), Iron-limited diatom growth and $\mathrm{Si}$ : N uptake ratios in a coastal upwelling regime, Nature, 393, 561-564, doi: $10.1038 / 31203$

Klaas, C., and D. E. Archer (2002), Association of sinking organic matter with various types of mineral ballast in the deep sea: Implications for the rain ratio, Global Biogeochem. Cycles, 16(4), 1116, doi:10.1029/ $2001 \mathrm{~GB} 001765$.

Koutavas, A., et al. (2002), El Nino-like pattern in ice age tropical Pacific sea surface temperature, Science, 297, 226-230, doi:10.1126/science. 1072376.

Leblanc, K., et al. (2005), Fe and $\mathrm{Zn}$ effects on the Si cycle and diatom community structure in two contrasting high and low-silicate HNLC areas, Deep Sea Res., Part I, 52, 1842-1864, doi:10.1016/j. dsr.2005.06.005.

Leynaert, A., et al. (2004), Effect of iron deficiency on diatom cell size and silicic acid uptake kinetics, Limnol. Oceanogr., 49, 1134-1143, doi:10.4319/lo.2004.49.4.1134.

Lisitzin, A. P. (1971), Distribution of siliceous micro fossils in suspension and in bottom sediments, in The Micropalaeontology of Oceans, edited by B. M. Funnell and W. R. Riedel, pp. 173-195, Cambridge Univ. Press, New York.

Malinverno, E., et al. (2008), Alkenone abundance and its relationship to the coccolithophore assemblage in Gulf of California surface waters, Deep Sea Res., Part I, 55, 1118-1130, doi:10.1016/j.dsr.2008.04.007.

Matsumoto, K., J. L. Sarmiento, and M. A. Brzezinski (2002), Silicic acid leakage from the Southern Ocean: A possible explanation for glacial atmospheric $p \mathrm{CO}_{2}$, Global Biogeochem. Cycles, 16(3), 1031, doi:10.1029/ 2001GB001442.

McClymont, E. L., R. S. S. Ganeshram, L. E. Pichevin, H. Talbot, B. van Dongen, R. C. Thunell, A. M. Haywood, J. S. Singarayer, and P. J. Valdes (2012), Sea-surface temperature records of Termination 1 in the Gulf of California: Challenges for seasonal and inter-annual analogues of tropical Pacific climate change, Paleoceanography, doi:10.1029/ 2011PA002226, in press. 
Moore, J. K., S. C. Doney, and K. Lindsay (2004), Upper ocean ecosystem dynamics and iron cycling in a global three-dimensional model, Global Biogeochem. Cycles, 18, GB4028, doi:10.1029/2004GB002220.

Morley, D. W., et al. (2004), Cleaning of lake sediment samples for diatom oxygen isotope analysis, J. Paleolimnol., 31, 391-401, doi:10.1023/B JOPL.0000021854.70714.6b

Mortlock, R. A., and P. N. Froelich (1989), A simple method for the rapiddetermination of biogenic opal in pelagic marine-sediments, Deep Sea Res., Part A, 36, 1415-1426, doi:10.1016/0198-0149(89)90092-7.

Nelson, D. M., et al. (1995), Production and dissolution of biogenic silica in the ocean: Revised global estimates, comparison with regional data and relationship to biogenic sedimentation, Global Biogeochem. Cycles, 9, 359-372, doi:10.1029/95GB01070.

Pena, L. D., I. Cacho, P. Ferretti, and M. A. Hall (2008), El NiñoSouthern Oscillation-like variability during glacial terminations and interlatitudinal teleconnections, Paleoceanography, 23, PA3101, doi:10.1029/ 2008PA001620.

Pichevin, L., E. Bard, P. Martinez, and I. Billy (2007), Evidence of ventilation changes in the Arabian Sea during the late Quaternary: Implication for denitrification and nitrous oxide emission, Global Biogeochem. Cycles, 21, GB4008, doi:10.1029/2006GB002852.

Pichevin, L. E., et al. (2009), Enhanced carbon pump inferred from relaxation of nutrient limitation in the glacial ocean, Nature, 459, 1114-1117. doi:10.1038/nature08101.

Pondaven, P., et al. (2000), Resolving the 'opal paradox' in the Southern Ocean, Nature, 405, 168-172, doi:10.1038/35012046.

Prange, M., et al. (2010), Inferring moisture transport across Central America: Can modern analogs of climate variability help reconcile paleosalinity records?, Quat. Sci. Rev., 29, 1317-1321, doi:10.1016/ j.quascirev.2010.02.029

Pride, C., R. Thunell, D. Sigman, L. Keigwin, M. Altabet, and E. Tappa (1999), Nitrogen isotopic variations in the Gulf of California since the Last Deglaciation: Response to global climate change, Paleoceanography, 14(3), 397-409, doi:10.1029/1999PA900004.

Ragueneau, O., et al. (2000), A review of the Si cycle in the modem ocean Recent progress and missing gaps in the application of biogenic opal as a paleoproductivity proxy, Global Planet. Change, 26, 317-365, doi:10.1016/S0921-8181(00)00052-7.

Ragueneau, O., et al. (2002), Si/C decoupling in the world ocean: Is the Southern Ocean different?, Deep Sea Res., Part II, 49, 3127-3154, doi:10.1016/S0967-0645(02)00075-9.

Reimer, P. J., et al. (2004), IntCal04 Terrestrial radiocarbon age calibration, 0-26 cal kyr BP, Radiocarbon, 46, 1029-1058.

Reynolds, B. C., et al. (2006a), Silicon isotope fractionation during nutrient utilization in the North Pacific, Earth Planet. Sci. Lett., 244, 431-443, doi:10.1016/j.epsl.2006.02.002.

Reynolds, B. C., et al. (2006b), Re-assessment of silicon isotope reference materials using high-resolution multi-collector ICP-MS, J. Anal. At. Spectrom., 21, 266-269, doi:10.1039/b515908c.

Reynolds, B. C., et al. (2006c), Abrupt cessation of north pacific upwelling with Northern Hemisphere Glaciation recorded by silicon isotopes, Geochim. Cosmochim. Acta, 70, A530-A530, doi:10.1016/j.gca.2006. 06.977 .

Roden, G. I. (1958), Oceanographic and meteorological aspects of the Gulf of California, Pac. Sci., 12, 21-45.
Sancetta, C. (1995), Diatoms in the Gulf of California: Seasonal flux patterns and the sediment record for the last 15,000 years, Paleoceanography, 10, 67-84, doi:10.1029/94PA02796.

Sarmiento, J. L., et al. (2004), High-latitude controls of thermocline nutrients and low latitude biological productivity, Nature, 427, 56-60, doi:10.1038/nature02127.

Sarmiento, J. L., J. Simeon, A. Gnanadesikan, N. Gruber, R. M. Key, and R. Schlitzer (2007), Deep ocean biogeochemistry of silicic acid and nitrate, Global Biogeochem. Cycles, 21, GB1S90, doi:10.1029/ 2006GB002720.

Segovia-Zavala, J. A., et al. (2010), Dissolved iron distributions in the central region of the Gulf of California, Mexico, Deep Sea Res., Part I, 57, 53-64, doi:10.1016/j.dsr.2009.10.007.

Stott, L. (2002), Super ENSO and global climate oscillations at millennial time scales, Science, 297, 222-226.

Takeda, S. (1998), Influence of iron availability on nutrient consumption ratio of diatoms in oceanic waters, Nature, 393, 774-777, doi:10.1038/ 31674.

Thunell, R. C. (1998), Seasonal and annual variability in particle fluxes in the Gulf of California: A response to climate forcing, Deep Sea Res., Part I, 45, 2059-2083, doi:10.1016/S0967-0637(98)00053-3.

Thunell, R., et al. (1993), Varve formation in the Gulf of California: Insights from time-series sediment trap sampling and remote-sensing, Quat. Sci. Rev., 12, 451, doi:10.1016/S0277-3791(05)80009-5.

Thunell, R., C. Benitez-Nelson, R. Varela, Y. Astor, and F. Muller-Karger (2007), Particulate organic carbon fluxes along upwelling-dominated continental margins: Rates and mechanisms, Global Biogeochem. Cycles, 21, GB1022, doi:10.1029/2006GB002793.

Wagner, J. D. M., et al. (2010), Moisture variability in the southwestern United States linked to abrupt glacial climate change, Nat. Geosci., 3 , 110-113, doi:10.1038/ngeo707.

White, A. E., F. G. Prahl, R. M. Letelier, and B. N. Popp (2007), Summer surface waters in the Gulf of California: Prime habitat for biological $\mathrm{N}_{2}$ fixation, Global Biogeochem. Cycles, 21, GB2017, doi:10.1029/ 2006 GB002779.

Ziveri, P., and R. C. Thunell (2000), Coccolithophore export production in Guaymas Basin, Gulf of California: Response to climate forcing, Deep Sea Res., Part II, 47, 2073-2100, doi:10.1016/S0967-0645(00)00017-5.

R. S. Ganeshram and L. Pichevin, School of Geosciences, Grant Institute, University of Edinburgh, West Main Road, Edinburgh EH9 3JW, UK. (laetitia.pichevin@ed.ac.uk)

E. L. McClymont, Department of Geography, University of Durham, South Road, Durham DH1 3LE, UK.

T. F. Pedersen, School of Earth and Ocean Sciences, University of Victoria, PO Box 3065 STN CSC, Victoria, BC V8W 3V6, Canada.

F. Prahl, College of Oceanic and Atmospheric Sciences, Oregon State University, Corvallis, OR 97331-5503, USA.

B. C. Reynolds, IGMR, ETH Zürich, Zürich, Clausiusstr. 25, CH-8092 Zürich, Switzerland.

R. Thunell, Department of Earth and Ocean Sciences, 700 Sumter St., University of South Carolina, Columbia, SC 29208, USA 